\title{
Character Development-based Physical Education Learning Model in Primary School
}

\author{
Tatang Muhtar*, Tedi Supriyadi, Anggi Setia Lengkana \\ Primary School Physical Teacher Education Study Program, Universitas Pendidikan Indonesia, Bandung, Indonesia
}

Received September 8, 2020; Revised October 27, 2020; Accepted November 11, 2020

\section{Cite This Paper in the following Citation Styles}

(a): [1] Tatang Muhtar, Tedi Supriyadi, Anggi Setia Lengkana, "Character Development-based Physical Education Learning Model in Primary School," International Journal of Human Movement and Sports Sciences, Vol. 8, No. 6, pp. 337 - 354, 2020. DOI: 10.13189/saj.2020.080605.

(b): Tatang Muhtar, Tedi Supriyadi, Anggi Setia Lengkana (2020). Character Development-based Physical Education Learning Model in Primary School. International Journal of Human Movement and Sports Sciences, 8(6), 337 - 354. DOI: 10.13189/saj.2020.080605.

Copyright $\odot 2020$ by authors, all rights reserved. Authors agree that this article remains permanently open access under the terms of the Creative Commons Attribution License 4.0 International License

\begin{abstract}
To foster good character through physical education, teachers need to have a conceptual framework that is used as a guideline in implementing the learning process that integrates character education in it. Therefore, this research aims at exploring and developing steps to foster good character in physical education learning that can be used as a guide for teachers by using 4D designs (Defining, Designing, Developing, and Disseminating). This research involved 200 primary school students in regency in West Java, Indonesia, and 30 physical education teachers from various regions in West Java, which was carried out using mixed-method research. This research resulted in several findings, including; 1) physical education teachers did not have a reference to the character learning model, so the characters developed were unclear, 2) there were nine characters that need to be developed in physical education learning in primary schools in West Java Province including respect, responsibility, caring, honest, fair, civilized, confident, togetherness, and religious, 3) to develop the nine characters, there were 10 steps that must be taken by the teacher in the learning process that is summarized in the INTEGRATED acronym namely Introduction, Narrative, Test/Pre-test, Education, Growth, Repetition, Action and Analysis, Training, Evaluation, and Doing, 4) the steps have been proven to grow nine characters in students in the learning process. The character was represented by $90 \%$ of students in every primary school in both urban and rural schools. Thus, to foster good character, the physical education learning process must implement the INTEGRATED Model in its learning.
\end{abstract}

Keywords Learning Models, Physical Education, Character Education

\section{Introduction}

Physical Education (PE) is an integral part of education which plays vital role in students [1]. Since it was founded, public schools have been concerned with morality, character education, or moral development [2], [3] in which. Sports have long been the subject of discussion in a formal curriculum of physical education in the development of moral qualities [4]-[7]. In philosophy and psychology, numerous traditions have sought to provide theoretical light on this complex issue and to give potential paths for pedagogical exploration. Good sports and good people that can give sound moral character and mature moral judgment are what sought. The phrase of 'sports build character' has also become a deep historical belief of coaches, educators, politicians, and clergy since ancient Greece [8]-[10]. However, there has not been much research on character education in the world of sports and physical education that can be traced to form solid scientific evidence [8], [11].

A tug of war on opinion related to moral development in physical education is caused by the many moral problems that are often seen in almost all sports matches. For example, a case of players who were beating a referee because they feel something was unfair or fighting between players. The forgery on the age of players also occurred in 
almost all sports such as tennis, swimming, athletics, soccer, badminton, volleyball, and so on. Besides, bribery in sports matches and the use of doping is a phenomenon that often emerged in the sports world. This is because the physical education process was considered failed to build the nation's character. After all, it is suspected that the learning process tends to be empty of values. Therefore, this research aims at exploring moral pedagogics to foster good character in physical education learning. It is hoped that the results of this research can become a conceptual framework that can be used as a guide for teachers in implementing physical education learning. Also, to achieve the goals of the character values that are grown on students, the need for learning models is a necessity [12]-[15].

Some research results related to character education in physical education at the same time distinguishes this research with others, for example; Pan, Huang, Lee, \& Hsu who examined the impact of different physical education curriculum model [16]. This research merged the Teaching Personal and Responsibility (TPSR), the Sport Education Model (SEM), and Traditional Teaching Model (TTM) to have better learning impacts in physical education classes in high school. The findings showed that, with dependent variables including sport self-efficiency, sports enthusiasm, responsibility, and game performance, the TPSR-SEM experimental group would better enhance the learning effects than the TPSR-TTM control group. TPSR-SEM is recommended to be developed in the physical education curriculum.

Sport Education (SE) is a curriculum model developed by Siedentop in 1994. Siedentop, (1998) affirms that "SE is a curriculum and instruction model designed to provide authentic, educationally rich sport experiences for girls and boys in the context of school physical education". In other words, this curriculum model is designed to provide real experiences to students regarding involvement in sports activities that are tailored to the context of physical education in schools. The main goal of SE is to build competent, literate, and enthusiastic sportsmen (students)[15]. Competent students are meant to be of sufficient ability to participate in good games, understand and be able to carry out appropriate strategies in complex games. Meanwhile, literate students are defined as those who understand the rules, rituals and traditions of sports and can distinguish between bad and good sports, whether in children's sports or professional sports. Enthusiastic goals are targeted so that students can participate in, maintain the values of sports, both in their roles as members of sports groups, and also enthusiastic participants in the development of local, national and international sports.[18].

Hellison's Teaching Personal and Social Responsibility (TPSR) learning model emphasizes on the affective domain [19]. This model aims at enhancing responsible attitudes built slowly through direct experiences experienced by students in physical activities starting from personal to social responsibility. Wright revealed that "the
TPSR model was a ground-breaking approach to teaching physical education and sport because it placed a primary emphasis on the affective domain"[20]. This model is considered effective to guide underserved students, which is supported by Hayden's opinion that "Hellison determined the most effective way to help underserved youth was to teach personal and social responsibility while connecting responsibility to particular values [21]". Furthermore, the TPSR model can regulate student behavior that must be achieved in learning by encouraging relationships among children to interact with one another. The Traditional Teaching Model is a model applying learning through demonstrations and commands in which teacher makes decisions and students follow [22].

Moreover, Thorburn [23] investigations concentrated on the prospect of making physical education an effective catalyst of policy and a contributing factor to the widely endorsed type of values of life. After an essential review on the related theorizations, thoughts are presented as to how core values can be consistently conceived in physical education and well-being. The discussion is based on the emergence of subjective and objective features, recognizing the importance of students' autonomy, contemplation, and respect for others. Then, it is reflected on how such values could shape learning procedures, such as an added importance of values on discourse and shared discussion, and methods utilizing language to make student can think clearer. The research concluded by showing how clearness about the values and pedagogical changes could contribute to the physical education in a time of increased policy expectation.

Abduljabar, also suggested that physical activity and sports can be an appropriate mediation choice in character education. Furthermore, he also revealed that character education through physical activities based on values can be an alternative to educating student characters by focusing on five levels of participation, namely; (1) respecting the rights and feelings of other students, (2) making efforts, (3) having a sense of self-direction, (4) helping other students, and (5) reflecting on activities outside of physical education [24].

Sumpana used smart card media to instill a culture of healthy living in physical education learning [25]. Meanwhile, Susanto researched the education of physical education teachers about character values in primary schools to identify character values in physical education learning [26]. The results of his research showed form of prototypes of character values arising in physical education learning that include cooperation, sportsmanship, honesty, fairness, caring, responsibility, respect, tough, friendly, competitive, persistent, mutual respect, togetherness, endurance, empathy, and determination. This showed that physical education subjects as a medium, have the opportunity to instill good character to the growing character [9]. Thus, Jay B Nash stated that character education is not likely to result from physical education activities if the principal or the stakeholders are more 
interested in winning games and making appearance in the media for themselves or their schools rather than building constructive behavior [27].

\section{Literature Review}

In the concept setting, character education is the process of instilling certain characters or values while providing seeds so that students can grow their distinctive character when running life [28]. Education is not only understood as a form of knowledge but also makes it a part of life and consciously lives based on ethical values [29], [30]. To foster good character, it must involve methods, techniques, and materials so that the goals of character education are achieved [31]. In other words, to achieve the goals of character values, a learning model is needed [12]-[15].

The term model can be interpreted as a conceptual framework that is used as a guide in carrying out an activity [32]. This means that the learning model is a conceptual framework describing a systematic procedure in organizing learning experiences to achieve certain learning goals and serves as a guide for learning designers and instructors in planning and implementing learning activities[33]-[38].

From the definition above, it can be understood that the function of the learning model is; 1) as a guideline, 2) as an aid in developing the curriculum, 3) as a reference in determining learning materials, and 4) as an assistance to improve the teaching process [39]. The model has the following characteristics; 1) based on educational theory and learning theory, 2) has a specific mission and goals, 3) as a guide for improving teaching and learning activities in class, (4) has a section called; (a) sequence of learning steps, (b) principles of reaction, (c) social systems, and (d) support systems, (5) has impacts as a result of applied learning models, (6) makes teaching preparations (instructional design) with guidelines for the chosen learning model [36], [40].

Joyce et. al , in their book entitled 'Model of Teaching', classified learning models into four groups namely: 1) the model group that processes information, which focuses on how educators and students can obtain, manage, and explain information well, and help students become superior learners, 2) social teaching model group that emphasizes on developing what can educators and students do together in creating a democratic atmosphere in society, and how social interaction can enhance the achievement of academic learning, 3) the group of the personal teaching model that aims at designing a school that adopts non-directive philosophy as the essence of the approach in teaching, and 4) a group model of behavioral systems that emphasizes on how to create learners who practice more productive behavior [34].

In the context of physical learning, several learning models emphasizing student character development have been offered by experts, for example, the Hellison model, which is often used to foster students' self-responsibility [19]. This model is often used in schools that have problems with student discipline. Basically, the Hellison model was created to help students understand and practice a sense of self-responsibility through physical education. Therefore, this model is often called The Personal and Social Responsibility learning model (TPSR)[10], [41] [43].

Further, the sports education model that was previously named play education [44] was developed by Siedentop [44]-[47]. This model is based on the Subject Matter, oriented towards Disciplinary Mastery values, and refers to the Sport Socialization curriculum model. This implies that this model can be used as an outline to teach character at school, since its values can be developed to instill good characters. The inspiration that underlies the emergence of this model is related to the fact that sport is one of the most important physical education materials used by physical education teachers and students like to do it. However, on the other hand, sports learning in the context of physical education are incomplete and inappropriately given to students because the values contained in it are often ignored. Then, there are many other models such as the Teaching Model of Respect from Strand and Reeder [48], the Cooperative Learning Model from Dyson [49] and the Teaching Values Model from Lumpkin, [42].

The number of models offered shows the amount of attention from academics and practitioners in developing an ideal physical education learning model. However, Metzler stated that there has been no learning model focusing on or promotes the realm of affective learning [15]. The neglect of the affective domain by the physical education teacher makes the learning process lacking development of character values, in which according to Destani because of the teacher's tendency to believe that morals or characters must be taught at home or because there is so much cultural diversity that is unclear about the values that must be taught. Many researchers also feel that the results of the realm of affective learning cannot be measured [50].

A study conducted by Xiang et al.,(2003) tested students' motivation in basic physical education using value-expectation model developed by Eccles his peers. Results indicated that expectancy related beliefs and subjective task values were obvious compared to another across physical education and throwing. These two constructs were positively related to each other, in which children's intention for future participation in physical education was positively linked with their subjective task values and/or expectancy-related beliefs. In addition, younger children had higher motivation for learning in physical education than older children. In relation to that, gender differences emerged, hence, the findings presented empirical evidence supporting the validity of the expectancy-value model in primary physical education.

Ntovolis et al.,'s (2015) research discovered that that primary school physical education plays a central role in promoting children's leisure time physical activity. The trans-contextual motivation model has been found to be 
effective in promoting physical education, which can affect students' leisure time physical activity. Initially, this model has been tested in secondary education, then when this model implemented in primary education, the results show that there is a significant mechanism on how motivation in primary school physical education can affect physical leisure activity. In addition, autonomous motivation in physical education in primary schools leads to high student intention on physical activity outside of school. Motivated by the statement above, this research is focused on promoting the realm of affective learning through physical education for primary school students in Indonesia, where children aged 6-12 years old attend primary schools. Character values grown through physical education learning in the context of this research are national character-based values developed at the primary school level [9], [53].

\section{Method}

\subsection{Research Design and Step}

The design development used in this research referred to the 4D model (Define, Design, Develop, and Disseminate) by Thiagarajan, Semmel, dan Semmel [54] combined with the design of Jolly \& Bolitho [55]. The designs are operationally mapped in four stages, namely; 1) at the define stage, field research is conducted to analyze the objective conditions for the physical education learning and analysis of character development needs, 2) at the design stage, a draft model is prepared based on the results of the field research or preliminary research, 3) at the development stage, a model test is conducted at several schools, and 4) at the disseminating stage, model socialization is carried out. Therefore, the research design developed seeks to produce new products that not only include material objects such as textbooks, learning films, and the like but also include procedures and learning processes [56]. This design was conducted under mixed-method research to address the objective of this research, which is to provide physical education teachers in Indonesia a conceptual framework used as a guideline in implementing the learning process integrating character education. Mixed-method research is considered suitable to help achieving this objective. Mixed-method research is one research procedure that collects, analyzes, and mixes quantitative method and qualitative in a research or a series of studies to comprehend research problem [57])

\subsection{Research Site and Participants}

This research was conducted in five primary schools where one primary school was in limited trials and four primary schools were in wider trials. It involved 200 students aged 10-11 years old from those five primary schools. The four schools are located in Sumedang Regency, West Java Province in three regional categories (urban, transitional, and rural) which were selected through purposive sampling, namely North Sumedang District, South Sumedang District, Ganeas District, and Darmaraja District. In addition, it also involved 30 physical education teachers as a collaborator team where these teachers acted as informants and as implementers of the learning model.

\subsection{Data Collection Technique}

Data collection was carried out using several techniques, namely field observations, interviews, FGDs, and surveys in August 2019. Therefore, the research instrument used consisted of observation guidelines, interview guidelines, and questionnaires. The survey was carried out using the Google Document facility using the Likert and Guttman scales [58], [59]. In today's digitalization era, Google Docs has become a profitable and easy-to-use survey tool [58][63]. Before the survey was administered, the physical education teachers in the school were asked to provide the data needed in this research activity by filling in the willingness form to fill out the survey form.

\subsection{Data Analysis Technique}

Data analysis was performed through qualitative and quantitative data analysis techniques. Qualitative data analysis was performed on data obtained through interviews, observations, and FGDs, while quantitative data analysis was conducted on observational and questionnaire data. To ensure the validity and reliability of those instruments, there were several techniques performed. The qualitative instruments were checked using triangulation [64], while the quantitative instruments were tested using content validity test and Cronbach's Alpha. Both of these data analysis were performed in the following procedure [65].

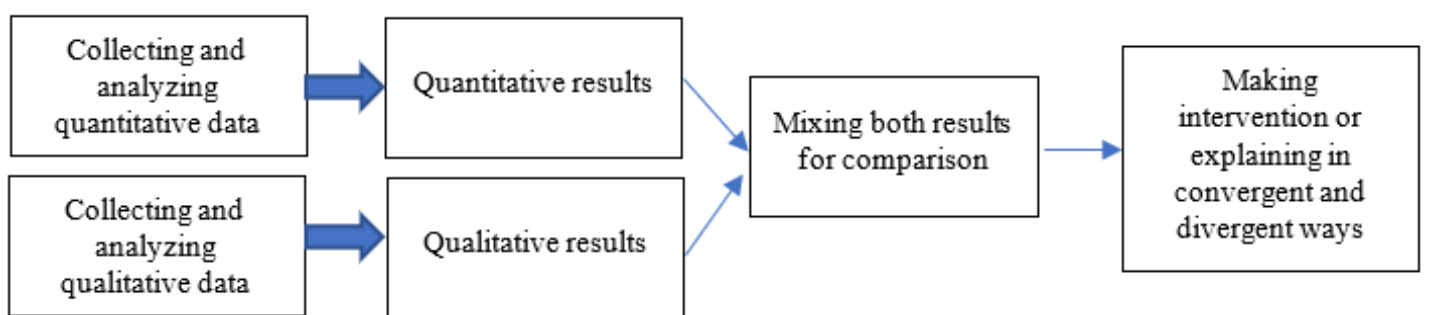

Figure 1. Data Analysis Technique 


\section{Results}

\subsection{Define}

A total of $30(100 \%)$ physical education teachers were surveyed and the survey results showed that $26(86.6 \%)$ physical education teachers did not have a model reference in implementing the learning process. Even from the models asked in Table 1, many teachers do not know them. Only four (13.4\%) teachers who claimed to refer to a model.

Next, a semi-structured interview was conducted on four teachers who claimed to use the model. The question posed is "What model do you use in the physical education learning process?" Teachers 1 and 2 answered "Using the CTL (contextual teaching and learning) model" and teachers 3 and 4 answered "Using the PBL (Project-Base Learning) model". This also indicated that the four teachers did not refer to the models developed in physical education learning because it was seen from the answers of all the teachers who answered did not know the Siedentop model, TPSR model from Hellison, or model from Lumpkin.

Based on the Table 1, a documentation study was carried out on the learning plan compiled by the teacher. The document examination aims at exploring whether the teachers included character values developed in learning planning or not? 30 teachers were asked to collect learning planning documents through Google Form. From the results of the examination, it was found that five (16.67\%) teachers listed the developed character values while the remaining $25(83.33 \%)$ did not mention them.
Table 1. Teacher Insight Survey Results Regarding Physical Education Learning Model

\begin{tabular}{lcc}
\hline \multicolumn{1}{c}{ Questions } & Yes & No \\
\hline $\begin{array}{l}\text { Does your learning process refer to one of the } \\
\text { learning models? }\end{array}$ & 26 \\
Do you know the cooperative learning model? & 30 \\
$\begin{array}{l}\text { Do you know the sports education models } \\
\text { developed by Siedentop? }\end{array}$ & 30 \\
$\begin{array}{l}\text { Do you know the Personal and Social } \\
\text { Responsibility (TPSR) learning model from }\end{array}$ & 30 \\
Hellison? \\
$\begin{array}{l}\text { Do you know the value learning model from } \\
\text { Lumpkin? }\end{array}$
\end{tabular}

From these findings, interviews were conducted with three teachers who did not include character values in the learning planning document. The question posed is "Why the written character values are not developed in the learning planning document?" Teacher 1 answered "Because the character is the realm of affection, so I want to know what characters emerged from material and techniques I taught." Teacher 2 answered "Because in the planning format, there is no component that requires including character values." Teacher 3 answered "Character is very difficult to assess, so it is enough to be observed." The answers raised indication that the character content in physical education learning tends to be blurred because it is not planned by the teachers.

The results of the interview encourage exploration of how teachers' perceptions of character learning in physical education. Using the Guttman scale, the results of the teachers' perception survey in character learning in physical education can be seen in the following table:

Table 2. Teacher's Perception about Character Learning in Physical Education

\begin{tabular}{|c|c|c|c|c|c|}
\hline Motivation & Very Disagree & Disagree & $\begin{array}{l}\text { Slightly } \\
\text { Disagree }\end{array}$ & Agree & $\begin{array}{l}\text { Very } \\
\text { Agree }\end{array}$ \\
\hline Physical education courses are full of national character values & & & & 27 & 3 \\
\hline $\begin{array}{l}\text { Physical education learning process can develop students' } \\
\text { character }\end{array}$ & & & & 30 & \\
\hline $\begin{array}{l}\text { Physical education subjects are able to produce students with } \\
\text { character }\end{array}$ & & & & 30 & \\
\hline
\end{tabular}


Table 2 above shows that the perceptions of teachers in the Sumedang regency believed that the subject of physical education requirements will be loaded with national character values. This can be inferred from 27 (90\%) people who agreed and $3(10 \%)$ people who strongly agreed with the statement. Likewise, the learning process and physical education learning outcomes can develop the character of students. The results of this survey indicated a common understanding that in the perception of physical education teachers, physical education subjects have a strategic position in the curriculum to develop students' character. However, from the survey results in Table 2, information through a survey about teachers' motivation in developing character values in physical education learning was explored. The survey result is presented in Table 3.

Table 3 illustrates that the motivation of teachers in learning characters was quite high. This can be seen from the statements of the teachers. $27(90 \%)$ teachers agreed and $3(10 \%)$ teachers strongly agreed that physical education teachers needed to understand character education. A total of $26(86.7 \&)$ teachers agreed and 4 $(13.3 \%)$ teachers strongly agreed that developing the character of students in physical education learning was an important requirement for teachers.

From the results of several surveys that have been conducted, it can be concluded that the Physical Education teachers in the Sumedang regency had not implemented character education well in physical education learning. This happened because they did not understand the concept of character education, even though their perceptions and motivations tended to be good but the implementation such as the survey results in Table 1 and interviews conducted showed that they did not have a good model and planning reference about character development in physical education learning.

Furthermore, to analyze what character values need to be developed in physical education learning in the Sumedang regency, a survey was conducted to 30 teachers. The questions in the survey refer to the results of an inventory of several research of the characters that appeared in physical education such as research results from Susanto, Abduljabar, Hellison and Lumpkin [24], [42], [66]-[68]. The results can be seen in the figure 2 .

Table 3. Teacher Motivation in Character Education

\begin{tabular}{|c|c|c|c|c|c|}
\hline Motivation & Very Disagree & Disagree & $\begin{array}{c}\text { Slightly } \\
\text { Disagree }\end{array}$ & Agree & $\begin{array}{l}\text { Very } \\
\text { Agree }\end{array}$ \\
\hline $\begin{array}{l}\text { Physical education teachers need to explore character } \\
\text { education }\end{array}$ & & & & 27 & 3 \\
\hline $\begin{array}{l}\text { Developing student character in physical education learning is } \\
\text { an important requirement for teachers }\end{array}$ & & & & 26 & 4 \\
\hline
\end{tabular}

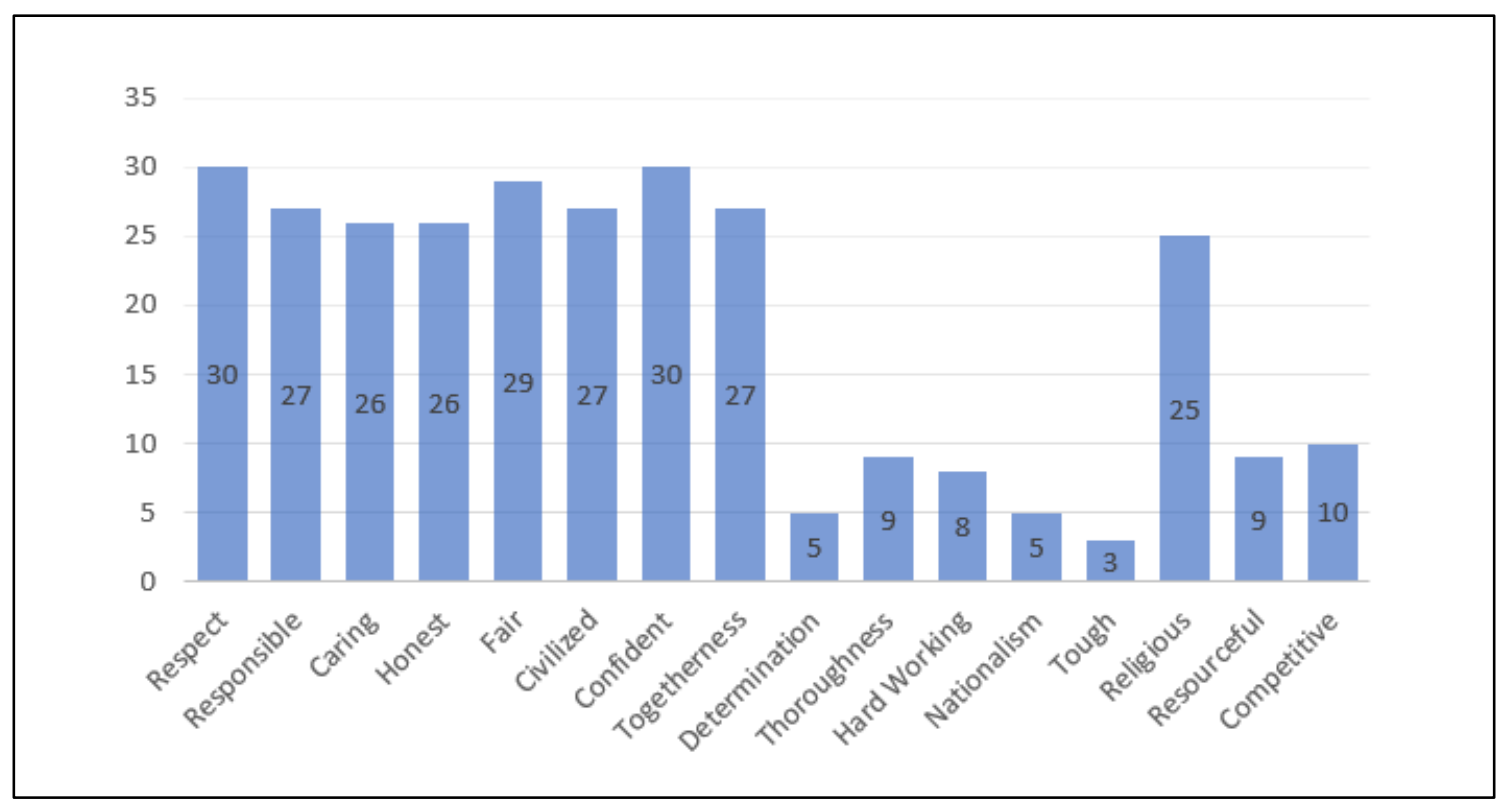

Figure 2. Character Survey Results that Need to Be Developed in Physical Education Learning 
From Figure 2 above, there are several characters that need to be developed in physical education learning. Of the 30 teachers surveyed, the most highlighted characters are; Respect by 30 (100\%) teachers, Responsible by 27 (90\%) teachers, Caring by $26(86.66 \%)$ teachers, Honest by 26 $(86.66 \%)$ teachers, Fair by $29(96.7 \%)$ teachers, Civilized by $27(90 \%)$ teachers, Confident by $30(100 \%)$ teachers, Togetherness by 27 (90\%) teachers, and Religious by 25 $(83.33 \%)$ teachers. While other character values such as Determination, Thoroughness, Hard-working, Nationalism, Tough, Resourceful, and Competitive, in the view of physical education, teachers have been considered quite successfully grown in physical education learning even though this requires further proof. However, the survey results above showed that the nine characters that are highlighted by many physical education teachers have not been optimally developed in the current physical education learning in Sumedang regency, so the learning design developed in the research is focused on developing the nine characters.

\subsection{Design}

As stated by Joyce, et. al, [34], the design developed in this research belongs to the group model of behavioral systems by emphasizing how to create students who practice more productive behavior through physical education learning so that students can develop behaviors that reflect nine characters namely Respect, Responsible, Caring, Honest, Fair, Civilized, Confident, Togetherness, and Religious. In addition, the main mission of this design is as a tangible manifestation of the succession of government programs in strengthening character education in schools. Therefore, to achieve these goals, a number of steps are taken in the effort to design learning designs. The steps are as follows:

\subsubsection{Designing Physical Education Learning Material with Character}

In the design of material on physical education with character, two modules are arranged. The first module contains the concept of character education. This module is oriented towards physical education teachers to improve their understanding of concepts. The second module is a physical education material with character for primary school students that will be used by teachers when providing physical education materials.

Referring to the results of the preliminary study, the first module is focused on providing understanding of character education in physical education. For example, how to teach values in physical education by referring to Lumpkin's theory that in learning, every teacher wants their students to judge something that is true, care deeply about what is right, and then do what they believe to be right [42]. Lumpkin's theory is strengthened by what is conveyed by Lickona that emphasized on the importance of the three components of good character namely moral knowing, moral feeling, and moral action[69]-[71].

In the module, it also explained the character development of students which is done through the optimization of the affective realm of physical education subjects that emphasized learning experiences related to one's emotions such as attitudes, interests, attention, awareness, and values directed in the form of the realization of affective behavior [72]. One way to optimize affective learning is that teachers must continue to show their commitment to the teaching of values by upholding and implementing the applicable code of ethics, including as stated in the Positive Coaching Alliance in Lumpkin's view of how teachers or trainers can teach by emphasizing developing aspects of respect and responsibility [42].

Susanto revealed that the strategy of teaching respect begins with the way the teacher shows respect for students, regardless of ethnicity, race, gender, and social status [26]. The teacher must be flexible in responding to the various levels of skills and abilities displayed by students. The best teaching plan for a teacher to teach respect to students is to always be vigilant and still respect students' attitudes and correct them at any time immediately which applies not only to certain students, but the whole class. Susanto also stated that moral education is based on teachers and teachers must show care and realize that students are unique individuals.

Teachers must explain that respect includes keeping promises to others, showing enthusiasm and enthusiasm to practice, practicing to improve fitness and sports skills, trying to help the team, never boasting or attracting attention to yourself, and never doing an attempt to embarrass yourself, the coach, or the school [26], [42].

Furthermore, responsibility is also an important trait for teachers or trainers to be implanted in students. Teachers need to emphasize that athletes or students must pay attention and follow instructions, concentrate on what they are doing, listen to constructive criticism, take initiative and open themselves, not make excuses or blame others, accept the consequences of their actions, ask for help when needed, and try to never let their colleagues down [42]. The growth of respect and responsibility will be the domino effect on the birth of other values in students such as trust, justice, attentive, honesty, courage, perseverance, integrity, and nationalism.

The second module designed physical education learning materials to develop nine characters as a result of the preliminary study. Broadly speaking, the scope of physical education learning materials is divided into three parts, namely games, sports, and health. In the game, material related to small ball games namely rounder is arranged. In sports, the material arranged is related to rhythmic gymnastics, and in health, the material is related to the habits of healthy living behavior. These materials are accompanied by the development of character values, for example, rounder will develop the character of respect, responsibility, togetherness, caring, honest, fair, civilized, 
confident, and religious.

\subsubsection{Designing Components of Physical Education Learning Model}

According to Rusman and Yazidi, learning model has the following components; (a) sequence of learning steps, (b) principles of reaction, (c) social systems, and (d) support systems [36], [40]. In accordance with these components, then the physical education learning model can be explained as follows:

\subsubsection{Syntax Design}

Syntax is a sequence of activities or phases. The syntax of physical education learning model based on character development consisted of 10 phases is presented in Table 4 , as follows:

Table 4. Syntax Design

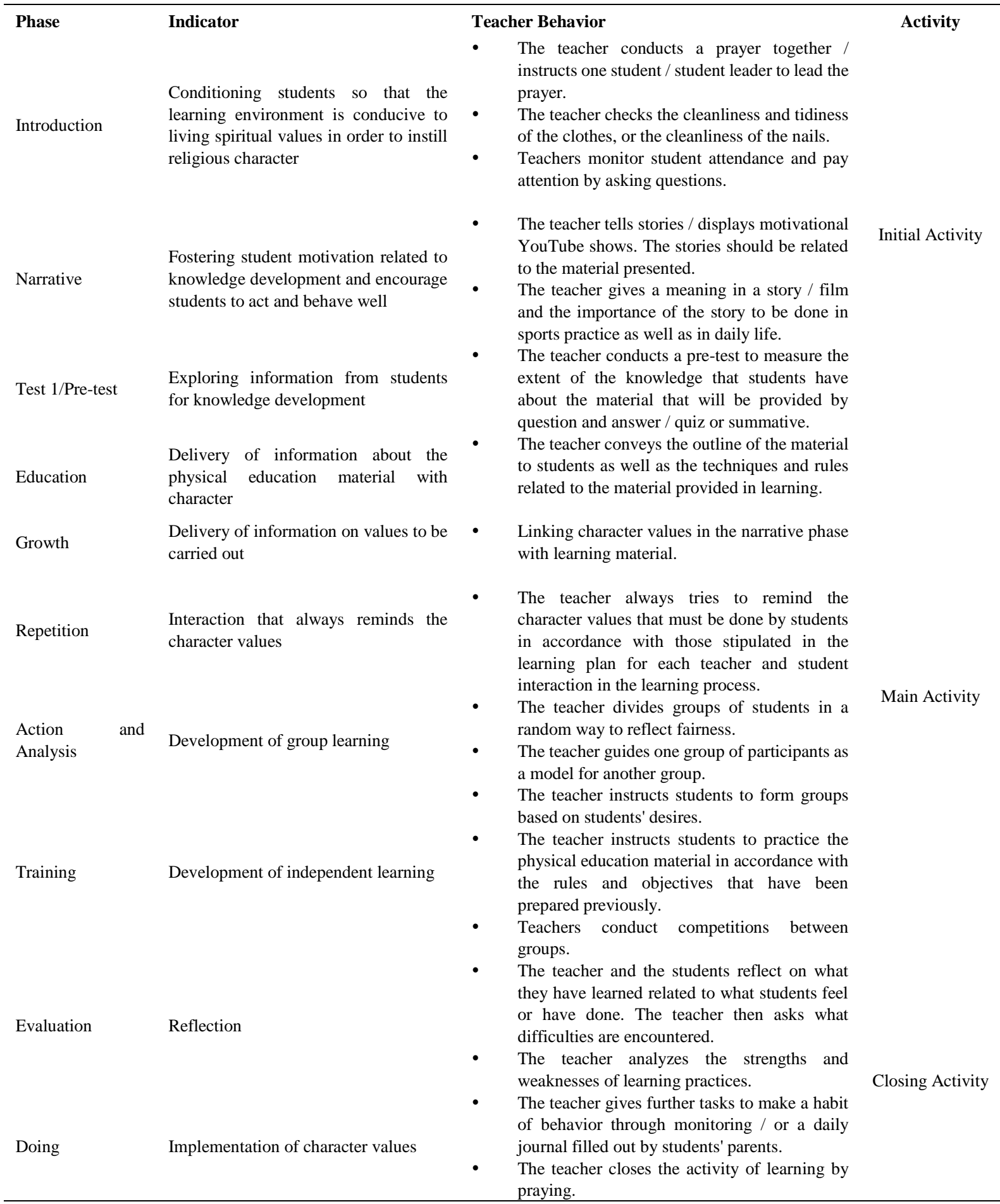


The phases above if collected in an acronym will be INTEGRATED (Introduction, Narrative, Test/pre-test, Education, Growth, Repetition, Action and Analysis, Training, Evaluation, and Doing) so that this learning design can be called integrated model. These phases are a conceptual framework that describes a systematic procedure in organizing learning experiences to achieve certain learning goals and serves as a guide for teachers in planning and implementing learning activities [33], [34].

In addition, this phase includes the configuration of characters in the context of the totality of psychological and socio-cultural processes initiated by the government in developing national character, namely; 1) spiritual and emotional development, 2) intellectual development, 3) physical and kinetic development, and 4) affective and creativity development. These four psycho-social processes are holistically and coherently interrelated and complement each other in the context of character building and the realization of noble values in a person [73].

\subsubsection{Reaction Principal}

There are several reaction principles in the integrated physical education learning model including the following: a). The teacher facilitates and directs students in improving students' knowledge, attitudes, and skills in physical activities.

b). The teacher observes social activities and changes as well as student attitudes as shown in the Student Work Sheet.

c). The teacher helps students by assisting if there are students who have difficulty in the process of improving collaborative skills.

d). The teacher helps students obtain broader information about how to improve collaborative skills and practice values through an integrated learning model.

\subsubsection{Social System}

The social system built in this integrated learning model is the creation of a conducive and pleasant atmosphere that occurs in the classroom. This is realized because the process of increasing spiritual and emotional intelligence runs naturally without coercion. Teacher interaction with students in a climate of friendship still shows the commitment of teachers who always emphasize on developing aspects of respect and responsibility.

\subsubsection{Supporting System}

The support system consists of a module of subject matter provided to students and a character education module for teachers as a guide. The lesson plan is the teacher's guideline for carrying out learning activities. Student worksheets (LKS, Lembar Kerja Siswa) are given to students to work on in groups and individually. A student observation sheet (questionnaire) is also needed to support this learning model as well as a daily journal filled by students' parents in observing students' daily behavior.

\subsubsection{Instructional Design}

Instructional design is the whole process of analyzing the needs and learning objectives and developing teaching techniques and teaching materials to meet those needs. This includes the development of lesson packages, teaching activities, trials, revisions, and evaluating learning outcomes [74]. It can also be interpreted that instructional design is a series of activities to study and describe core competencies (general instructional objectives) into basic competencies of indicators or more specific goals. In this stage, the instructional design is arranged with the following components; 1) determine core competencies, 2) determine basic competencies and indicators of achievement of basic competencies, 3) set learning objectives, 4) compile learning scenarios consisting of preliminary activities, core activities, and closing activities by integrating the syntax that has been designed as a learning model and distinguished from other models, and 5) develop evaluation instruments.

\subsubsection{Instructional Impact}

The instructional impact of the integrated physical education learning model consists of:

a). Understanding physical activities based on strengthening national character.

b). Feeling the sensation of physical activities carried out and able to live up to the values that are internalized in students through physical activity.

c). Practicing national character values through physical activities.

d). Independence in learning positive physical activity, sharing knowledge, and experiences.

e). Motivating themselves to learn and develop collaborative skills with group friends and peers through activities.

f). Actualizing the values that have been grown on physical activities in daily life to foster good relations with others in their environment.

\subsubsection{Accompaniment Impact}

The accompaniment impacts of the integrated physical education learning model are:

a). Students have knowledge about physical activities based on strengthening national character, especially respect and responsibility.

b). Students can feel the sense of physical activities carried out and are able to live the values to be practiced through physical activities.

c). Students are able to practice national character values through physical activities.

d). Students can grow independence in learning physical activity positively, sharing knowledge, and experience.

e). Students can motivate themselves to learn and develop collaborative skills with group friends and peers through physical activities. 
f). Students can actualize the values that have been grown on physical activities in daily life to foster good relations with others in their environment.

\subsubsection{Results of Model Design/Hypothetical Model}

Based on the descriptions above, the integrated physical education learning model in developing students' character can be described as figure 3 .

\subsection{Develop}

This stage is the development stage. Model development was carried out in two stages, namely the model validation test stage by the expert and the model testing stage.

\subsubsection{Validation Test}

Validation test was done before the hypothetical model is tested by conducting Focus Group Discussion (FGD). The validation test involved two elements namely the academic element and the practitioner element. From academic element, it involves two people, one person who is an expert in the field of character education and one expert in the field of physical education. From practitioner element, the person involved is one physical education teacher. In the validation test, the assessment and input of the two elements are assessed using a scale of 1 to 5 . The results of the validation test are presented in the following Table 5:

Table 5. Validation Test Results

\begin{tabular}{llllc}
\hline \multirow{2}{*}{ Assessed Aspect } & \multicolumn{2}{c}{ Academic } & Practitioner \\
& & Aspect & Aspect \\
1. & Syntax & 4 & 4 & 5 \\
2. & Reaction Principle & 4 & 4 & 4 \\
3. & Social System & 4 & 4 & 4 \\
4. & Supporting System & 5 & 4 & 4 \\
5. & Instructional Design & 4 & 4 & 5 \\
\hline & $\quad$ Total Value & 21 & 2 & 22 \\
& Mean & 4.2 & 4 & 4.4 \\
\hline
\end{tabular}

Value: 5 = Very Good, 4 = Good, 3 = Quite Good, 2 = Bad, 1 = Very Bad

\section{Integrated Physical Education Learning Model}

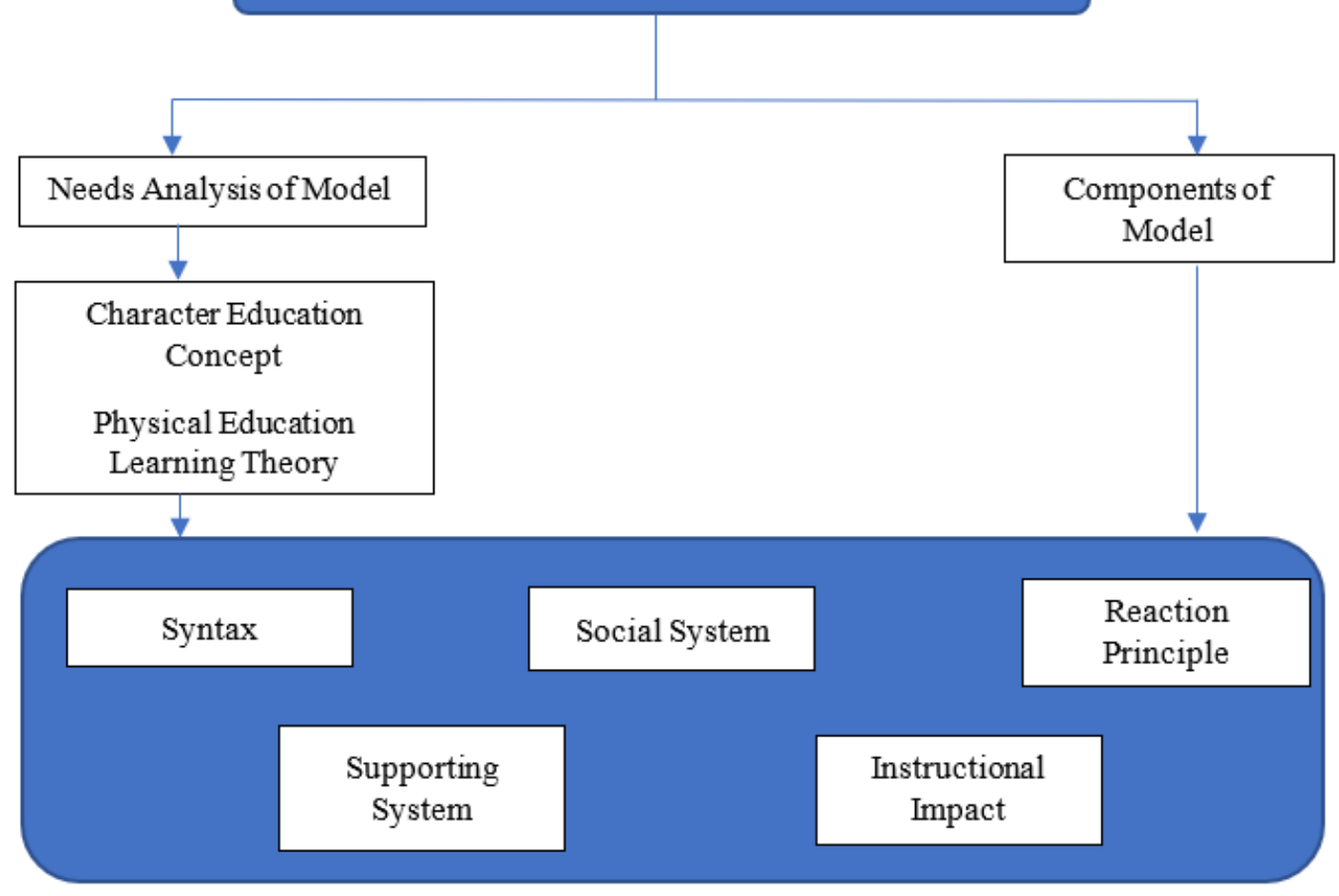

Figure 3. The Hypothetical Physical Education Learning Model with Character 
Table 5 above shows that each element on the integrated physical education learning model has been assessed. Character education experts give an average rating of 4.2 and physical education experts give an average rating of 4 . The teacher element gives an average grade of 4.4. This means that the assessment of each element has a good tendency on the hypothetical learning model, in the sense that this model is accepted by a team of experts and can be tested. However, there are some inputs from the expert team related to the material designed in the form of modules. Among them are:

1. Clarify the learning instructions

2. Simplify the language used in the module

3. Insert the illustrated images in the module

4. Insert forms as internalization of character values

\subsubsection{Model Testing}

After the input from the expert team is followed up, the development of the model enters the next stage which is the testing phase. This stage is the trial phase of the model and the possibility of product revisions to the model. The trial was conducted in two phases, the first was a limited trial set at one school with a total of 40 students. The schools used as the object of this limited model trial are the school in urban areas. The second trial was conducted in four schools in all urban, transitional, or rural areas with 40 students in each school. Every school in the trial phase was accompanied by a physical education teacher at the school.

\subsubsection{Limited Trial}

Figure 4 shows the results of testing an integrated learning model in physical education. Based on Figure 4, the nine characters developed through the integrated physical education model are successfully represented in student behavior. For example, religious characters are 21 $(53 \%)$ students, respect characters are 27 (68\%) students, responsibility characters are $22(55 \%)$ students, caring characters are $26(65 \%)$ students, honest characters are 18 (45\%) ) students, fair character are $20(50 \%)$ students, civilized character are $22(55 \%)$ students, confident character are $23(58 \%)$ students, and togetherness character are $21(53 \%)$ students. The instrument and technical assessment followed the research conducted by Muhtar, et. al (2020) and Suherman, et. al (2019).

To maximize the results of character development, there are several revisions based on input from the teacher as a collaborator in research. Based on the teacher's input, the revision focused on aspects of improving learning scenarios such as the opening activity. Initially, the teacher instructed the students to lead the prayer before learning as a technique for growing religious character, but such setting was revised by bringing students together to pray. In this case, the teacher is directly involved so that togetherness and civilization can be felt. In addition to praying for themselves, to foster student care and respect, they were also invited to pray for their friends who were absent from class because of illness.

Revisions were also made in the preliminary settings related to providing motivation to students to grow the character of self-confidence which at first only through verbal motivational stories was revised with emphasizing on audio visual media such as videos or short films. In addition, the meaning of the story or films presented is not directly conveyed by the teacher but is asked first to the students. After that, the teacher concluded it. In the core activities, revisions are aimed at learning media that are used such as using modified tools from students' own creativity. In the closing activity, the teacher initially concluded the material and explored the value, it is revised by asking students to reflect on the material that has been delivered and what behaviors can be applied in daily life.

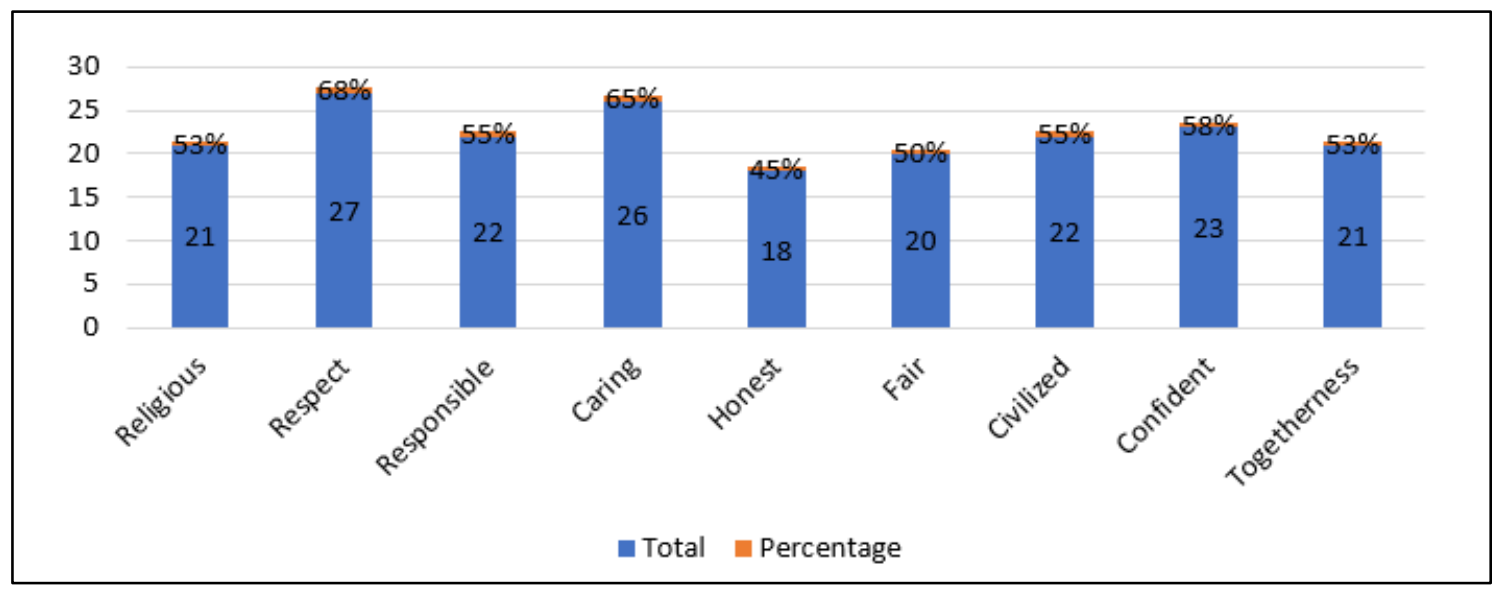

Figure 4. Pre-Revised Model Trial Results 


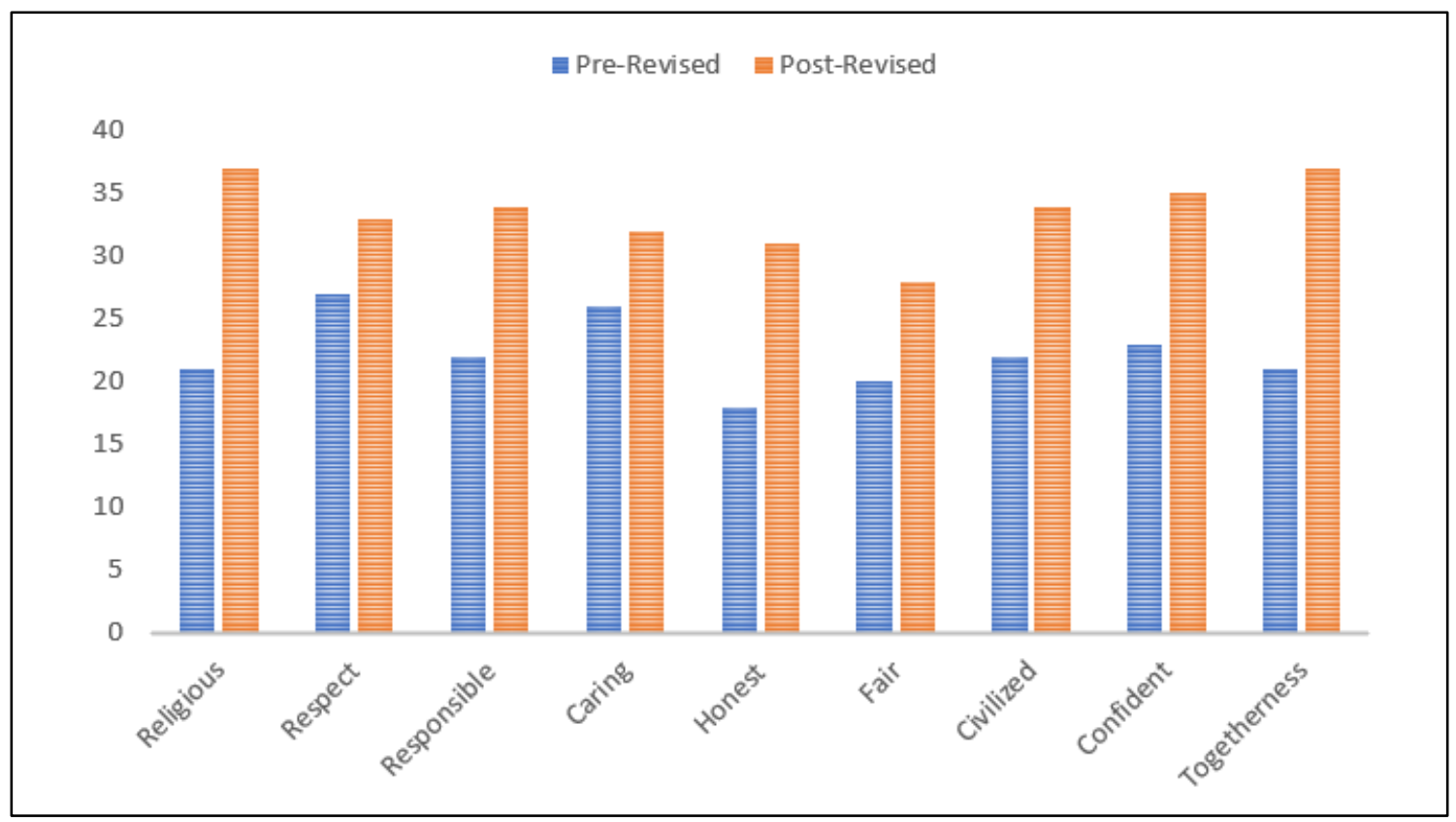

Figure 5. Post-Revised Model Trial Results

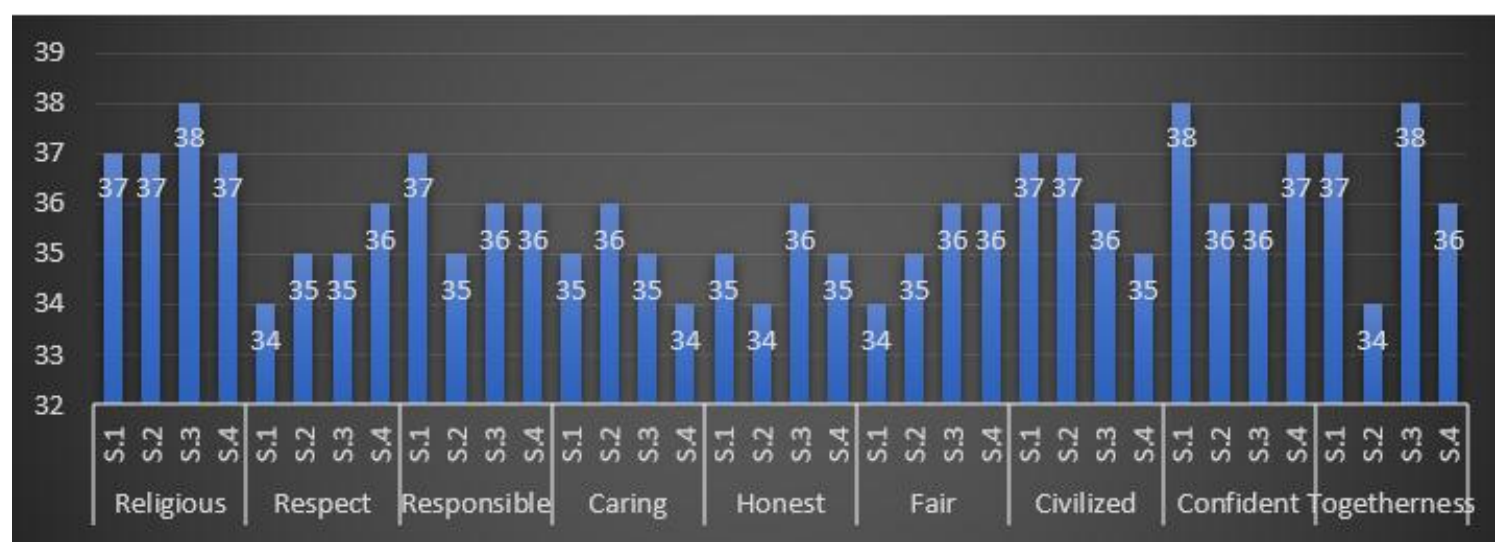

Description: S.1 = First School, S.2 = Second School, S.3 = Third School, and S.4 = Fourth School

Figure 6. Wider Trial

The results of the improvement or revision are then re-tested and the evaluation results showed an increase in the number of students who represent the nine characters as in Figure 5.

\subsubsection{Wider Trial}

Figure 6 depicts the test results at four schools. It also showed the tendency of nine characters represented in student behavior when learning physical education. The average number of students who represented each character in each school is $35.86(90 \%)$. This also showed that there is no large gap between schools in urban, transitional, and rural areas. It also showed that the integrated physical education learning model is able to develop these nine characters.

\subsection{Disseminating}

After the product was tested, the next step was to socialize this integrated physical education model product to the physical education teachers in the Sumedang regency, West Java. The socialization was carried out in the form of a seminar related to the implementation of the character-based physical education learning model, which was attended by 60 physical education teachers in the Sumedang regency. After the workshop was conducted, a survey related to the material presented was conducted. The survey was given to 60 teachers to dig up information about the perception of the teachers about the integrated physical education learning model. The survey results are presented in the following Table 6: 
Table 6. Dissemination Activity Survey Results

\begin{tabular}{|c|c|c|c|c|c|c|}
\hline No. & Statement & Very Disagree & Disagree & $\begin{array}{l}\text { Slightly } \\
\text { Disagree }\end{array}$ & Agree & $\begin{array}{l}\text { Very } \\
\text { Agree }\end{array}$ \\
\hline 1 & $\begin{array}{l}\text { The integrated physical education learning } \\
\text { model can be easily understood }\end{array}$ & & & 1 & 45 & 14 \\
\hline 2 & $\begin{array}{l}\text { The integrated physical education learning } \\
\text { model is important to be mastered by physical } \\
\text { education teachers }\end{array}$ & & & & 50 & 10 \\
\hline 3 & $\begin{array}{l}\text { The integrated physical education learning } \\
\text { model must be immediately implemented in } \\
\text { learning process }\end{array}$ & & & 2 & 43 & 15 \\
\hline 4 & $\begin{array}{l}\text { The integrated physical education learning } \\
\text { model is full of character education content }\end{array}$ & & & & 53 & 7 \\
\hline 5 & $\begin{array}{l}\text { The integrated physical education learning } \\
\text { model is an innovative learning model }\end{array}$ & & & & 55 & 5 \\
\hline
\end{tabular}

Table 6 above provides information about teachers' perceptions regarding the integrated physical education learning model that are quite good. Based on the survey results, most teachers stated it was easy to understand the model and considered it important to master the model. In addition, from the statements submitted, most teachers also stated that it was important to immediately implement the model in the learning process. Then, in their perception too, the integrated physical education learning model is full of character education contents and is an innovative learning model.

\section{Discussion and Conclusions}

The results of this research provide a new understanding that for the growth of good character in physical education learning, it must involve methods, techniques, and materials so that the objectives of character education are achieved [31]. The results of this research also showed the fact that by implementing the integrated physical education learning model, the purpose of this model, which are fostering nine characters in students' behavior in the learning process, can be reached. This showed that teachers need to constantly develop their competencies.

The ability of teachers to develop learning model implied that teachers must also have literacy skills by exploring studies that can improve their abilities. For example, the study of how teacher learning is researched and proposed or discussed models of teacher professional learning [75]-[79]. This is done so that teachers can learn and change by developing theory or applying theory to the teaching process[33], [80]. Teacher competency improvement needs to be done so that teachers can carry out their duties properly and achieve success in teaching. According to Joyce, Weil, and Calhoun [34], successful teachers are not just a charismatic and persuasive presenter. Further, successful teachers are those who engage students in cognitive and social loaded tasks and teach them how to do the tasks productively. One of the causes of unsuccessful teaching is the habit of a teacher teaching unprofessionally and the habit of teaching instantly, and less concerned with the changes in students.

One of the causes of teacher failure in growing student character is the paradigm used in education tends to emphasize more head start (IQ intelligence) than heart start (emotional intelligence) [81], [82]. The head start paradigm emphasizes that children "must be able to" until there is a tendency for children to learn too early (early childhood training). Cases such as anti-social personality disorder, learning disability, etc. are born from the head start education paradigm [81]. Therefore, a reconstruction of education is needed in building a new paradigm of education [83]-[85]. The new educational paradigm is a paradigm that is not only focuses on changes in cognitive and psychomotor aspects but also affection aspects because the education process is not only a transfer of knowledge but also a transfer of values[86] and the main key to the birth of this paradigm must be in line with the motivation of teachers to innovate and to change [87]-[89].

Therefore, there is no complete education without the presence of physical education and there is no good quality physical education without the presence of qualified teachers [89]-[91]. Teacher quality is believed to be an important factor in learning physical education in schools [19], [92], [93]. This means that to build character in physical education, a professional teacher is needed, namely teachers who are able to integrate character education in physical education learning[90], [91], [94], [95]. Teacher professional learning is a complex process, which requires cognitive and emotional involvement of teachers individually and collectively, the capacity and willingness to examine where each one stands in terms of convictions and beliefs and the perusal and enactment of appropriate alternatives for improvement or change [96].

Related to the above results, it can be concluded that in order to become a qualified physical education teacher, teachers must be able to implement 10 phases in the physical education learning process. The 10 phases are summarized in an INTEGRATED acronym (Introduction, Narrative, Test/pre-test, Education, Growth, Repetition, Action and Analysis, Training, Evaluation, and Doing). These 10 phases have proven capable of developing nine good characters in physical education including respect, 
responsibility, caring, honest, fair, civilized, confident, togetherness, and religious. This research also showed empirical evidence that physical education can develop good character in students. In fact, the nine characters are represented by $90 \%$ of students in the physical education learning process. Therefore, it is recommended for Physical Education teachers to master this INTEGRATED model in order to develop and instill good characters of their students.

\section{Limitation}

This research certainly has several limitations, including; 1) the target of this research is primary school students, 2) the values developed are limited to nine characters, and 3) the focus of this research is limited to physical education learning. Therefore, to expand the research in this topic, it is very possible to conduct research in the development of physical education at the higher education levels.

\section{Acknowledgement}

The authors extend their gratitude to the Universitas Pendidikan Indonesia for funding grants for this research. The grant reference number is the Decree of Rector of Universitas Pendidikan Indonesia No: 508/UN40.D/PT/2020.

\section{Appendix}

Survey 1. Teacher Insight Survey Results Regarding Physical Education Learning Model

\begin{tabular}{ll}
\hline Questions & Yes \\
\hline Does your learning process refer to one of the learning models? & No \\
Do you know the cooperative learning model? \\
Do you know the sports education models developed by Siedentop? \\
Do you know the Hellison's Personal and Social Responsibility (TPSR) learning model? \\
Do you know the value learning model from Lumpkin? \\
\hline
\end{tabular}

Survey 2. Teacher's Perception about Character Learning in Physical Education

\begin{tabular}{|c|c|c|c|c|c|}
\hline Motivation & Very Disagree & Disagree & $\begin{array}{c}\text { Slightly } \\
\text { Disagree }\end{array}$ & Agree & $\begin{array}{l}\text { Very } \\
\text { Agree }\end{array}$ \\
\hline \multicolumn{6}{|l|}{ Physical education courses are full of national character values } \\
\hline \multicolumn{6}{|l|}{$\begin{array}{l}\text { Physical education learning process can develop students' } \\
\text { character }\end{array}$} \\
\hline $\begin{array}{l}\text { Physical education subjects are able to produce students with } \\
\text { character }\end{array}$ & & & & & \\
\hline
\end{tabular}

Survey 3. Teacher Motivation in Character Education

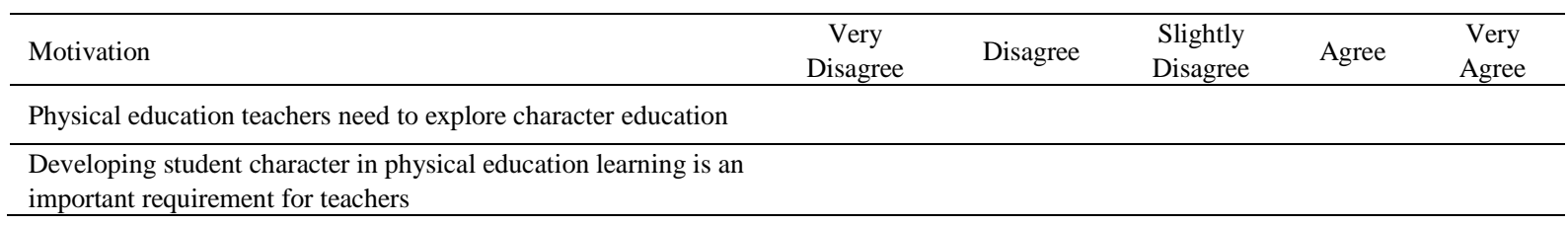


Survey 4. Character to Be Developed in Physical Education Learning

\begin{tabular}{cc}
\hline Characters & Yes \\
\hline Respect & No \\
Responsible & Caring \\
Honest & Fair \\
Civilized & Confident \\
Togetherness & Determination \\
Thoroughness & Hardworking \\
Nationalism & Tough \\
Religious \\
Resourceful \\
Competitive
\end{tabular}

Survey 5. Dissemination Activity

\begin{tabular}{|c|c|c|c|c|c|c|}
\hline No. & Statement & Very Disagree & Disagree & $\begin{array}{l}\text { Slightly } \\
\text { Disagree }\end{array}$ & Agree & $\begin{array}{l}\text { Very } \\
\text { Agree }\end{array}$ \\
\hline 1 & $\begin{array}{l}\text { The integrated physical education learning } \\
\text { model can be easily understood }\end{array}$ & & & & & \\
\hline 2 & $\begin{array}{l}\text { The integrated physical education learning } \\
\text { model is important to be mastered by physical } \\
\text { education teachers }\end{array}$ & & & & & \\
\hline 3 & $\begin{array}{l}\text { The integrated physical education learning } \\
\text { model must be immediately implemented in } \\
\text { learning process }\end{array}$ & & & & & \\
\hline 4 & $\begin{array}{l}\text { The integrated physical education learning } \\
\text { model is full of character education content }\end{array}$ & & & & & \\
\hline 5 & $\begin{array}{l}\text { The integrated physical education learning } \\
\text { model is an innovative learning model }\end{array}$ & & & & & \\
\hline
\end{tabular}

\section{Interview Guideline}

1. Are you active in the forum of Physical Education teachers?

2. Have the teacher forum discussed strengthening character education?

3. Have you ever studied the concept of character education?

4. Did you get any character education materials during lectures?

5. Did you get any character education materials from the training?

6. Do you master the concept of character education?

7. Do you always make lesson plans?

8. In preparing the lesson plan, did you determine what characters would be developed in the material?

9. In your Physical Education teaching practice, do you always carry out what has been planned in the lesson planning?

10. What model do you use in the Physical Education learning process?

11. Can the learning model be implemented?

12. Do you always try to develop the model?

13. How do you measure the achievement of the characters developed in Physical Education learning?

\section{REFERENCES}

[1] L. N. Chukwurah, O. I. Abbah, C. N. Iweama, J. E. Ogugua, and J. Ameh, "Students' Achievement in Physical and Health Education: Effect of Discussion Teaching Metho," Int. J. Hum. Mov. Sport. Sci., vol. 8, no. 3, pp. 86-90, 2020. https://doi: 10.13189/saj.2020.080302.

[2] G. E. Figley, "Moral education through physical education," Quest, vol. 36, no. 1, pp. 89-101, 1984. https://doi: $10.1080 / 00336297.1984 .10483804$

[3] K. Mouratidou, S. Goutza, and D. Chatzopoulos, "Physical education and moral development: An intervention programme to promote moral reasoning through physical education in high school students," Eur. Phys. Educ. Rev., vol. 13, no. 1, pp. 41-56, 2007. https://doi: $10.1177 / 1356336 \times 07072675$

[4] P. J. Arnold, "Sport And Moral Education," J. Moral Educ., vol. 23, no. 1, pp. 75-89, 1994. https://doi: 10.1080/0305724940230106.

[5] P. J. Arnold, "The Virtues, Moral Education, and The Practice of Sport," Quest, vol. 51, no. 1, pp. 39-54, 1999. https://doi: 10.1080/00336297.1999.10491667. 
[6] C. Bailey, "Games, Winning and Education," Cambridge J. Educ., vol. 5, no. 1, pp. 40-50, 1975. https://doi: 10.1080/0305764750050105.

[7] D. Carr, "What moral educational significance has physical education? A question in need of disambiguation," Ethics Sport, pp. 119-133, 1998.

[8] Ali Maksum, "Olahraga membentuk karakter: Fakta atau mitos," J. Ordik, vol. 3, no. 1, pp. 23-30, 2005.

[9] A. Suherman, T. Supriyadi, and S. H. I. Cukarso, "Strengthening National Character Education Through Physical Education: An Action Research in Indonesia," Int. J. Learn. Teach. Educ. Res., vol. 18, no. 11, pp. 125-153, 2019. https://doi: 10.26803/ijlter.18.11.8.

[10] M. R. Weiss, A. L. Smith, and C. P. Stuntz, "Moral development in sport and physical activity.," 2008.

[11] Ali Maksum, "Riset Karakter dalam Pendidikan Jasmani," in "Implementasi nilai-nilai luhur olahraga dalam pembentukan karakter melalui Pendidikan jasmani, 2017, pp. 1-11. [Online]. Available: https://www.researchgate.net /publication/321185180.

[12] Z. Yun-fei, "Reflection on Carrying out Club Model in Physical Education Teaching of Colleges and Universities," JOURNAL-SHANGHAI Phys. Educ. INSTITUTE., vol. 28, pp. 92-94, 2004.

[13] M. DeBusk and D. Hellison, "Implementing a physical education self-responsibility model for delinquency-prone youth," J. Teach. Phys. Educ., vol. 8, no. 2, pp. 104-112, 1989.

[14] S. C. Wortham, Early childhood curriculum: Developmental bases for learning and teaching. Kevin M. Davis, 2006.

[15] M. Metzler, Instructional models in physical education. Routledge, 2017.

[16] Y.-H. Pan, C.-H. Huang, I. Lee, and W.-T. Hsu, "Comparison of learning effects of merging TPSR respectively with Sport Education and Traditional teaching model in high school physical education classes," Sustainability, vol. 11, no. 7, p. 2057, 2019. https://doi: 10.3390/su11072057.

[17] D. Siedentop, "What is sport education and how does it work?," J. Phys. Educ. Recreat. Danc., vol. 69, no. 4, pp. 18-20, 1998. https://doi: 10.1080/07303084.1998.10605528

[18] R. Kurniawan, "Penerapan SEM (Sport Education Model) dalam Konteks Kurikulum 2013," 2018. https://doi: 10.31227/osf.io/vgua7

[19] D. R. Hellison and others, "Teaching responsibility through physical activity.," Teach. Responsib. through Phys. Act., 1995.

[20] P. Wright, "Standing on the Shoulders of Giants: R. Tait McKenzie Address," Phys. Heal. Educ. J., vol. 85, no. 1, pp. $1-15,2019$.

[21] L. A. Hayden, The power of a caring climate: assessing the fidelity of team support to Hellison's responsibility model and student-athletes perceived outcomes of participating in team support. Boston University, 2010.

[22] K. Theodorakou and Y. Zervas, "The Effects of the Creative
Movement Teaching Method and the Traditional Teaching Method on Elementary School Children's Self-esteem," Sport. Educ. Soc., vol. 8, no. 1, pp. 91-104, Jan. 2003. https://doi: 10.1080/1357332032000050088.

[23] M. Thorburn, "Values, autonomy and well-being: Implications for learning and teaching in physical education," Educ. Stud., vol. 40, no. 4, pp. 396-406, 2014. https://doi: $10.1080 / 03055698.2014 .930338$.

[24] B. Abduljabar, "Memperkokoh Pendidikan Karakter melalui Mediasi Aktivitas Jasmani Berbasis Nilai," J. Pendidik. Karakter, no. 2, pp. 97-107, 2014. https://doi: 10.21831/jpk.v0i2.2180.

[25] V. A. L. Sumpana, "Pengembangan Pembelajaran Penjasorkes Pada Materi Menerapkan Budaya Hidup Sehat Menggunakan Media Kartu Pintar Untuk Siswa Kelas IV Di SDN Sekaran 01 Kecamatan Gunung Pati Kota Semarang Tahun 2013," Act. J. Phys. Educ. Sport. Heal. Recreat., vol. 3, no. 9, 2014. https://doi: 10.15294/active.v3i9.3607.

[26] E. Susanto, "Pembelajaran Pendidikan Jasmani Berbasis Karakter Untuk Meningkatan Nilai-nilai Afektif Di Sekolah Dasar," J. Pendidik. Karakter, no. 3, 2013. https://doi: 10.21831/jpk.v0i3.2751

[27] Jay B Nash, "The Rôle of Physical Education in Character Education," J. Health Phys. Educ., vol. 4, no. 3, pp. 28-69, 1933. https://doi: 10.1080/23267240.1933.10625629.

[28] L. Andriany, Model Pendidikan Karakter Di Perguruan Tinggi. Riau: PT. Anugerah Semesta Persada, 2016.

[29] K. Ryan, K. E. Bohlin, and S. N. McDonnell, Building character in schools: Practical ways to bring moral instruction to life. Jossey-Bass San Francisco, 1999.

[30] S. R. Rindrayani, "The Implementation of Character Education in Indonesia High School Curriculum Program," Univers. J. Educ. Res., vol. 8, no. 1, pp. 304-312, 2020. https://doi: 10.13189/ujer.2020.080137.

[31] T. Licona, Educating for character: how our school can teach respect and responsibility. New York: Bantambooks, 1991. https://doi: 10.1177/019263659207654519

[32] U. S. Winataputra, "Model-Model Pembelajaran Inovatijf Mengajar di Perguruan Tinggi," Jakarta(PAU-PPA-UT) Univ. Terbuka, 2005.

[33] D. Clarke and H. Hollingsworth, "Elaborating a model of teacher professional growth," Teach. Teach. Educ., vol. 18, no. 8, pp. 947-967, 2002. https://doi: 0.1016/s0742-051x(0 2)00053-7.

[34] E. Joyce, B. Weils, M. Calhoun, Models of Teaching. USA: Alyn and Bacon, 1996. https://doi: 10.1086/443124.

[35] N. Nurdyansyah and E. F. Fahyuni, "Inovasi Model Pembelajaran Sesuai Kurikulum 2013.” Nizamia Learning Center, 2016.

[36] Rusman, Model-model pembelajaran: mengembangkan profesionalisme guru. Rajawali Pers/PT Raja Grafindo Persada, 2011.

[37] T. Tayeb, "ANALISIS DAN MANFAAT MODEL PEMBELAJARAN," AULADUNA J. Pendidik. Dasar Islam, vol. 4, no. 2, pp. 48-55, 2017. 
[38] Trianto., Mendesain Model Pembelajaran Inovatif Progesif. Jakarta: Bumi Aksara, 2010.

[39] L. Iru and L. O. S. Arihi, "Analisis penerapan pendekatan, metode, strategi, dan model-model pembelajaran," Yogyakarta: Multi Presindo, 2012.

[40] A. Yazidi, "Memahami Model-model Pembelajaran Dalam Kurikulum 2013 (the Understanding of Model of Teaching in Curriculum 2013)," J. Bahasa, Sastra, dan Pembelajarannya, vol. 4, no. 1, pp. 89-95, 2014.

[41] P. A. Hastie and A. M. Buchanan, "Teaching responsibility through sport education: Prospects of a coalition," Res. $Q$. Exerc. Sport, vol. 71, no. 1, pp. 25-35, 2000. https://doi: 10.1080/02701367.2000.10608877.

[42] A. Lumpkin, "Teachers as role models teaching character and moral virtues," J. Phys. Educ. Recreat. Danc., vol. 79, no. 2, pp. 45-50, 2008. https://doi:10.1080/07303084.2008. 10598134.

[43] T. Martinek, T. Schilling, and D. Johnson, "Transferring personal and social responsibility of underserved youth to the classroom," Urban Rev., vol. 33, no. 1, pp. 29-45, 2001. https://doi: 10.1023/A:1010332812171.

[44] A. E. Jewett, "Curriculum theory and research in sport pedagogy.," Sport Sci. Rev., 1994.

[45] D. Siedentop, "Developing teaching skills in physical education.," 1976.

[46] D. Siedentop and H. der Mars, "Introduction to physical education, fitness, and sport," 2004.

[47] D. Siedentop, "Quality PE through positive sport experiences: Sport education," Champaign, Hum. Kinet., 1994.

[48] B. Strand and S. Reeder, "Increasing physical activity through fitness integration," J. Phys. Educ. Recreat. Danc., vol. 67, no. 3, pp. 41-47, 1996. https://doi: 10.1080/07303084.1996.10607220.

[49] B. Dyson, "Cooperative learning in an elementary physical education program," J. Teach. Phys. Educ., vol. 20, no. 3, pp. 264-281, 2001. https://doi: 10.1123/jtpe.20.3.264.

[50] F. Destani, J. C. Hannon, L. Podlog, and T. A. Brusseau, "Promoting Character Development through Teaching Wrestling in Physical Education," J. Phys. Educ. Recreat. Danc., vol. 85, no. 5, pp. 23-29, 2014. https://doi: 10.1080/07303084.2014.897570.

[51] P. Xiang, R. McBride, J. Guan, and M. Solmon, “Children's Motivation in Elementary Physical Education: An Expectancy-Value Model of Achievement Choice," Res. Q. Exerc. Sport, vol. 74, no. 1, pp. 25-35, Mar. 2003. https://doi 10.1080/02701367.2003.10609061.

[52] Y. Ntovolis, V. Barkoukis, E. Michelinakis, and H. Tsorbatzoudis, "An application of the trans-contextual model of motivation in elementary school physical education," Phys. Educ., vol. 72, no. 5, 2015. https://doi: 10.18666/TPE-2015-V72-I5-5111.

[53] T. Muhtar, T. Supriyadi, A. S. Lengkana, and S. Hanifah, "Religious Characters-Based Physical Education Learning in Elementary School," Int. J. Learn. Teach. Educ. Res., vol. 18, no. 12, 2020. https://doi: 10.26803/ijlter.18.12.13.
[54] S. Thiagarajan, D. S. Semmel, and M. I. Semmel, "Instructional development for training teachers of exceptional children." Minneapolis, Minnesota: Leadership Training Institute/Special Education ..., 1974.

[55] D. Jolly and R. Bolitho, "A framework for materials writing," Mater. Dev. Lang. Teach., pp. 107-134, 2011.

[56] M.. Borg, W.R. \& Gall, Educational Research: An Introduction, Fifth Edition. New York: Longman, 2003.

[57] J. W. Creswell and V. L. P. Clark, Designing and conducting mixed methods research. Sage publications, 2017.

[58] I. E. Allen and C. A. Seaman, "Likert scales and data analyses," Qual. Prog., vol. 40, no. 7, pp. 64-65, 2007.

[59] W. Widhiarso, "Skalo program analisis skala Guttman," Yogyakarta, Indones. Univ. Gajah Mada, 2011.

[60] T. J. Brigham, “Taking advantage of Google's Web-based applications and services," Med. Ref. Serv. Q., vol. 33, no. 2, pp. 202-210, 2014. https://doi: 10.1080/02763869.2014.897 521.

[61] C.-H. Chiu, H.-W. Cheng, and C.-Y. Wu, "Applying questioning or reading strategy to review technology enhanced coedited notes of elementary school students," $J$. Educ. Res., vol. 109, no. 2, pp. 111-121, 2016. https://doi: $10.1080 / 00220671.2014 .924471$.

[62] Y.-T. Lin, C.-H. Chang, H.-T. Hou, and K.-C. Wu, "Exploring the effects of employing Google Docs in collaborative concept mapping on achievement, concept representation, and attitudes," Interact. Learn. Environ., vol. 24, no. 7, pp. 1552-1573, 2016. https://doi: $10.1080 / 10494820.2015 .1041398$.

[63] L. Travis, "One of many free survey tools: Google docs," J. Electron. Resour. Med. Libr., vol. 7, no. 2, pp. 105-114, 2010. https://doi: 10.1080/15424065.2010.482902.

[64] S. J. Tracy, “Qualitative quality: Eight 'big-tent' criteria for excellent qualitative research," Qual. Inq., vol. 16, no. 10, pp. 837-851, 2010. https://doi: 10.1177/1077800410383121.

[65] E. G. Carmines and R. A. Zeller, Reliability and validity assessment, vol. 17. Sage publications, 1979. https://doi: $10.4135 / 9781412985642$.

[66] E. Susanto, "Pengetahuan Guru Tentang Nilai-Nilai Karakter Pembelajaran Pendidikan Jasmani Sekolah Dasar," J. Pendidik. Karakter, no. 1, 2012. https://doi: 10.21831/jpk.v0i1.1454.

[67] D. R. Hellison, "Physical education and the self-attitude," Quest, vol. 13, no. 1, pp. 41-45, 1970. https://doi: 10.1080/00336297.1970.10519675.

[68] D. R. Hellison, "Humanistic physical education.," 1973.

[69] T. Lickona, "Moral Development and Behavior: Theory, Research, and Social Issues.," 1976. https://doi: $10.2307 / 582353$.

[70] T. Lickona, "The return of character education.," Educ. Leadersh., vol. 51, no. 3, pp. 6-11, 1993.

[71] T. Lickona, Educating for character: How our schools can teach respect and responsibility. Bantam, 2009.

[72] K. Hansen, "Teaching within all three domains to maximize 
student learning," Strategies, vol. 21, no. 6, pp. 9-13, 2008 https://doi: 10.1080/08924562.2008.10590794.

[73] Kemendiknas, "Desain induk pendidikan karakter," Jakarta: Kemendiknas, 2010.

[74] R. M. Gagne and J. Leslie, "Briggs (1979)," Princ. Instr. Des., 1979.

[75] K. Castle, "Autonomy through pedagogical research," Teach. Teach. Educ., vol. 22, no. 8, pp. 1094-1103, 2006. https://doi: 10.1016/j.tate.2006.07.001.

[76] J. D. Novak and D. B. Gowin, Learning how to learn. Cambridge University Press, 1984.

[77] M. James and R. McCormick, "Teachers learning how to learn," Teach. Teach. Educ., vol. 25, no. 7, pp. 973-982, 2009. https://doi: 10.1016/j.tate.2009.02.023.

[78] J. Nisbet and J. Shucksmith, Learning strategies. Routledge, 2017. https://doi: 10.4324/9781315188652

[79] M. R. Olson and C. J. Craig, “Opportunities and challenges in the development of teachers' knowledge: The development of narrative authority through knowledge communities," Teach. Teach. Educ., vol. 17, no. 6, pp. 667684, 2001. https://doi: 10.1016/s0742-051x(01)00023-3.

[80] C. Penlington, "Dialogue as a catalyst for teacher change: A conceptual analysis," Teach. Teach. Educ., vol. 24, no. 5, pp. 1304-1316, 2008. https://doi: 10.1016/j.tate.2007.06.004.

[81] M. Ratna, "Pendidikan Karakter," Jakarta Indones. Herit. Found., 2009.

[82] R. Megawangi, "Pendidikan karakter solusi yang tepat untuk membangun bangsa," Jakarta Indones. Herit. Found., 2004.

[83] J. Tagg, The learning paradigm college. Anker Publishing Company Bolton, MA, 2003.

[84] M. Savin-Baden and C. H. Major, Foundations of problem-based learning. McGraw-Hill Education (UK), 2004.

[85] R. B. Barr and J. Tagg, "From Teaching to Learning-A New Paradigm For Undergraduate Education," Chang. Mag. High. Learn., vol. 27, no. 6, pp. 12-26, 1995. https://doi: 10.1080/00091383.1995.10544672.
[86] J.Julia and Tedi Supriyadi, "The Implementation of Character Education at Senior High School," in Global Conference on Teaching, Assessment, and Learning in Education (GC-TALE 2017), 2017, pp. 1-6. https://doi: $10.1051 /$ shsconf/20184200085.

[87] G. McCulloch, Educational reconstruction: The 1944 education act and the twenty-first century. Routledge, 2013.

[88] G. Mcculloch, "Curriculum reform, educational change and school improvement," in International handbook of educational change, Springer, 1998, pp. 1203-1215. https://doi: 10.1007/978-94-011-4944-0_56

[89] G. Helsby and G. McCulloch, "Teacher professionalism and curriculum control," in Teachers' professional lives, Routledge, 2002, pp. 64-82.

[90] M. B. Postholm, "Teachers' professional development: a theoretical review," Educ. Res., vol. 54, no. 4, pp. 405-429, 2012. https://doi: 10.1080/00131881.2012.734725.

[91] J. Loughran, "Professionally developing as a teacher educator," J. Teach. Educ., vol. 65, no. 4, pp. 271-283, 2014. https://doi: 10.1177/0022487114533386.

[92] A. Kohn, "How not to teach values: A critical look at character education," Phi Delta Kappan, vol. 78, pp. 428439, 1997.

[93] D. Docheff, "Character in Sport and Physical Education," $J$. Phys. Educ. Recreat. Danc., vol. 68, no. 9, p. 34, 1997. https://doi: 10.1080/07303084.1997.10605026.

[94] P. Cordingley et al., "Developing great teaching: lessons from the international reviews into effective professional development.," 2015.

[95] C. Lonsdale, R. R. Rosenkranz, L. R. Peralta, A. Bennie, P. Fahey, and D. R. Lubans, "A systematic review and meta-analysis of interventions designed to increase moderate-to-vigorous physical activity in school physical education lessons," Prev. Med. (Baltim)., vol. 56, no. 2, pp. 152-161, 2013. https://doi: 10.1016/j.ypmed.2012.12.004.

[96] B. Avalos, "Teacher Professional Development in Teaching and Teacher Education Over Ten Years," Teach. Teach. Educ., vol. 27, no. 1, pp. 10-20, 2011. https://doi: 10.1016/j.tate.2010.08.007. 